\title{
GODSOORDEEL EN GEREGTELIKE TWEEKAMP
}

Tius was by die Germane tegelyk god van die stryd en god van die reg. Die begrip, dat die oorwinning van liggaamskrag en moed in die stryd tewens die oorwinning van die reg sou wees, is heidens-germaans en nie christelik nie. Tog was daar 'n tydvak van honderde jare in die geskiedenis van die christelike Europa, waarin om so te sê elke siviele of kriminele hofsaak deur 'n geregtelike tweekamp met die wapens kon beslis word, waarvan die uitslag deur kerk en owerheid as 'n godsoordeel aanvaar is. ${ }^{1}$ ) Die reëls van die stryd is in landswette, stadskeure en gewoontereg vasgelê, maar die daarby gebruiklike ritueel het meer en meer 'n aangeleentheid van die christelike kerk geword. In die dertiende eeu begin die vervanging van die ,duellum" - soos die geregtelike tweekamp in middeleeuse bronne genoem word - deur ander prosesmiddele of deur ander godsoordele, maar eers in die sestiende eeu sterf die „kampreg" uit. Die beroemde Nederlandse juris Damhoudere noem dit in 1555 nog in sy „Praxis rerum criminalium”. In Groot-Brittanië het in 1817 'n sekere Thornton, van moord beskuldig, op grond van die kampreg geëis, dat hy sou toegelaat word om sy. aanklaer in 'n duel te beveg; en toe laasgenoemde daartoe geen lus gevoel het, is Thornton vrygespreek!

Die vraag wat ons hier sal besig hou is: hoe het die geregtelike tweekamp sy karakter van 'n godsoordeel gekry, en wat was die houding van die christelike kerk teenoor hierdie in wese volkome onchristelike gebruik?

Met 'n vry groot sekerheid kan ons sê dat die geregtelike tweegeveg reeds voor die eintlike Middeleeue ontstaan het. Die oudste geskrewe wette van die Germaanse stamme, die ,leges barbarorum”, spreek meesal daarvan in terme wat dui op 'n algemeen bekende, gevestigde regsinstituut:

"Tunc spondeant inter se pugnam duorum . . ." (Lex Alleman. 84, Lex Bajuv. 17, 2),

„.. . vulneribus campus judicat" (Lex Thuring. 15),

„Si occupator contradixerit, c a m po. dijudicetur" (Lex Saxonum 5, 3).

Wel is waar spreek die oudste wet, wat die duellum vermeld, die Lex Gundobada Burg. van 501, van 'n nuwe gebruik, maar bedoel is, dat die

1) Beugnot noem in sy uitgawe van die "Assises de Jérusalem" (Paris, 1841) selfs die $13 \mathrm{e}$ eeu: ,... une époque, où le duel dominait tout le système de procédure civile et criminelle". 
duellum daar op 'n nuwe manier gebruik word, nl. om meineed van getuies of van ,eedhelpers" teen te gaan.

In die klassieke wêreld het die geregtelike tweegeveg nie bestaan nie en die Romeine het ook nie geweet hoe dit by die Germane gereël was nie. Tacitus in sy Germania (cap. 10, slot) praat wel van 'n tweegeveg, maar dit is nie geregtelik nie. Velleius Paterculus (Hist. Rom. 2,118 ) praat van ,,armis discerni" as hy die vete-reg bedoel, wat 'n ander instelling is.

'n Brief van Cassiodorus, namens koning Theoderik tot die Pannoniërs gerig, waarin hy hulle aanmaan om as beskaafde mense die „monamachia" te laat staan, getuig van die afkeer wat 'n Romein van hierdie "barbaarse" gebruik het, maar gee tewens bewyse, hoe sterk die duellum by die Pannoniërs ingeburger was (Cassiodorus, Var. III ep. 24). Uit die vyfde boek van Saxo Grammaticus blyk, dat hy daarvan oortuig was, dat die duellum selfs reeds in die eerste eeue van ons jaartelling in Denemarke gebruiklik was. Die oud-Noorse saga-literatuur tenslotte bewys dat van die vroegste historiese tye af Noorweë en Ysland die duellum geken het, al was dit meesal slegs half-geregtelik.

Met sekerheid kan ons sê dat die duellum Germaans van oorsprong is en deur Germane Wes-Europa toe gebring is. Ewemin as die Romeine het die Kelte dit geken. In Ierland is dit eers deur die Engelse ingevoer, maar in Engeland self is dit gebring deur die Normandiese verowering in 1066.

Die enigste Germaanse stamme waarvan ons nie kan bewys dat hulle die duellum toegepas het nie, is die Angel-Sakse, waar dit onder Keltiese invloed kan verdwyn het en die Wes-Gote, waar Romeins-Keltiese invloed kan gewerk het.

Hierdie Germaanse geregtelike tweekamp het oorspronklik niks met 'n godsoordeel te doen nie. Ons wil hierdie stelling verdedig, hoewel groot regshistorici soos Esmein en BrunNer die teëdeel beweer. ${ }^{2}$ )

Toegegee moet word dat die meeste ,leges barbarorum" die duellum reeds as 'n godsoordeel voorstel: ,... tunc per pugnam ad Dei Judicium decernatur" (Leges Longob. I, 3 par 6). Volgens Richthofen (Fries. Rechtsquellen p. 408) sê die reg van Friesland beweste die Lauwers: „Camp is dera fyf ordela Godes een": of wel: „die tweegeveg is een van die vyf vorme van godsoordeel". Die christelike Lex Burgund. motiveer dit selfs deur te sê dat God die uitslag van nasionale oorloë bestuur en dus ook die regverdige party in die duellum sal laat wen.

Ons begin egter reeds en twyfel as ons sien dat Koning Liutpraud in 'n wet van 713, wat in die Leges Longob. voorkom (tit. 9, par. 23), die duellum 'n ,impia consuetudo" noem ,quia incerti sumus de

2) A. Esmrin, „Cours élément. d'hist. du droit franç” o.a. H. Brunner, „Deutsche Rechtsgeschichte", le Aufl., p. 414-418. 
judicio Dei". Hoewel hy dit onchristelik vind, vra hy 'n verbod daarvan slegs in die geval van baie ernstige misdrywe, aangesien dit by sy volk nou eenmaal 'n ingewortelde gewoonte is.

En as Karel die Grote in 'n capitulare van 809 (cap. 20) moet voorskrywe ,ut omnes judicio Dei credant absque dubitatione" en hy sluit daarby uitdruklik die duellum in, dan bewys hy alleen maar dat in sy tyd die geloof aan die duellum qua godsoordeel nie te sterk was nie.

Ons konklusie kan dus ten hoogste wees dat van die $6 \mathrm{e}$ tot die $8 \mathrm{e}$ eeu getrag word om die geregtelike tweekamp as 'n christelike godsoordeel voor te stel. Maar aangesien ons reeds weet dat die duellum ouer is as die kerstening van die Germane, moet ons nou dus nagaan of dit tevore dan 'n heidense godsoordeel was. Dit lyk as of ' $n$ bewysplaas uit die Lex Bajuv. (XI, 5) hiervoor pleit, waar die duellum genoem word „pugna quae Wehadinc vocatur”. Die uitleg „weha-dinc is heilige gereg" is egter verkeerd, aangesien "weha" hier nie van wihsacer is afgelei nie, maar van wig-stryd.

Trouens, ons glo in die algemeen nie, dat godsoordele 'n oudgermaanse oorsprong het nie. Veeleer is hulle onder christelike en oosterse invloed in Wes-Europa ingevoer. Die Germane het hulle gode nie as alwetend beskou nie en ook nie as opreg nie. Hoe kan dan van hulle die onthulling van waarheid en die betoon van regvaardigheid verwag word? Hulle gode handel in die saga's party keer iuis immoreel as teken van hul bo-menslikheid, want hulle is nie aan die menslike wette van moraal gebind nie. Van hulle kan mens 'n orakel verwag, nie 'n godsoordeel nie.

Die eintlike godsoordele, soos die vuurproef, kom meesal nie voor die 9e eeu voor nie, en die noord-Germane in Skandinawië het dit in hulle nasionale kultuur nooit geken nie. Die beste bewys egter dat die Germane die godsoordeel slegs by oordrag ken en partykeer selfs meganies oorgeneem het, sonder om dit te verstaan, is die volgende: Naas die egte godsoordele of ,,ordales" het hulle toegelaat "teë-ordales" wat deur die teëparty op tou gesit word, „versterkte ordales" wat 'n gewone godsoordeel moet oortref, „onegte ordales" soos die lot en die kruisproef en tenslotte die onderwerping van 'n plaasvervanger van klaer of beklaagde aan die godsoordeel. Dit is alles instellings wat bewys dat die sin van die godsoordeel aan die betrokke volke ontgaan het.

Kan ons dus beswaarlik aanneem dat by die Germane die godsoordeel primêr aanwesig was en dat die duellum sekundêr daaruit afgelei sou gewees het, daar is bowedien baie uiterlike verskille tussen die twee instellings: Fy die egte godsoordeel handel slegs èèn van die twee partye en hy verwag die goeie uitslag nie van sy verrigtings nie maar van 'n wonder. Slegs by uitsondering getuig die wonder tee $n$ die beklaagde: alleen in die watertoets wat 'n latere ontaarding is, wat meesal by hekse-prosesse gebruik is, en in die baar-toets, waarby die lyk aangeraak word, wat oorspronklik 'n orakel was. By die duellum neem 
altwee partye aan die toets deel en daar word nie 'n wonder, maar 'n natuurlike afloop verwag. 'n Merkwaardige verskil is voorts dat die duellum uitsluitend tussen vry manne geveg word en dat vir onvryes, priesters, vrouens en ander onstrydvaardige kategorieë die godsoordeel voorbehou is.

Slegs skynbaar pleit die kruis-toets teen ons opvatting: wel is waar neem altwee partye daaraan deel en word daar geen wonder verwag nie, maar die verklaring is dat ons hier met 'n onbloedige godsoordeel te doen het, wat juis later deur die christelike kerk ingevoer is om die bloedige duellum te vervang.

Tenslotte is die duellum vir enige hofsaak toegestaan, tot selfs in die geringste siviele vordering, terwyl die godsoordeel altyd voorbehou word vir gevalle, waarin ' $n$ persoon die begaan van ' $n$ misdaad ontken.

Op grond van die bostaande verwerp ons die mening dat die duellum oorspronklik 'n ewentuele heidense godsoordeel was.

Ons beskou die duellum eenvoudig as die oorspronklike ,ultima ratio legis" by die Germane. Reeds MonTesQuieu het daarop gewys. dat die toelaat van negatiewe bewysmiddels in die oud-germaanse reg. vanself tot die duellum gelei het. ${ }^{3}$ ) Die eed van 'n beklaagde wat ontken, gestaaf deur die eed van sy helpers of ,cojurantes”, word gewraak deur die teëparty. Hierdie wraking is tegelyk ' $n$ belediging want dit verklaar die eed tot 'n meineed. Die gevolg sou dan wees 'n duellum. Inderdaad vind ons in Burgundië waar die getuiebewys vrywel ontbreek, en die eed met cojurantes die meeste toegepas word, ook die meeste gevalle van geregtelike tweegeveg (Lex Gundab. Burg., VIII vir kriminele en XLV vir siviele sake).

Later sal die beroemde historikus R. FRUIN in dieselfde rigting soek as Montesquieu: die duellum is nie, soos die godsoordeel, 'n bewysmiddel nie, maar die laaste middel om 'n hofsaak uiteindelik te besleg, wat nie op 'n ander manier opgelos kan word nie. Hy sê: „Evenals in het volkenrecht nog heden ten dage, beslist in het privaatrecht van de eerste Middeleeuwen de overmacht in hoogste ressort." ${ }^{\text {) }}$ As ons die duellum beskou as "ultima ratio legis" kan ons ook verklaar hoe dit samehang met die gewone tweegeveg wat ons reeds in die oudste germaanse saga's vermeld vind.

- Die geregtelike tweegeveg het ontstaan deurdat 'n oorspronklik buite-geregtelike tweekamp, tengevolge van verskeie juridiese nosies, in bepaalde gevalle die gewone oud-germaanse hofsaak òf gaan vervang het, of daarin opgeneem is.

3) MONTEsquieu gee in die 28ste boek van sy "Esprit des Lois" 'n uitvoerige bespreking van die duellum.

4) R. FruIN, ,Over waarheid, kenning en zeventuig in de rechtspleging van Holland en Zeeland." Verspr. Geschr. Deel VI, p. 321 vlg. 
Dit is algemeen bekend hoe formalisties die oud-germaanse proses was, aangesien die regsformules (dingtale) oorspronklik magies-religieuse betekenis gehad het. Wie hierdie formalisme skend deur onwetendheid of deur onagsaamheid loop gevaar om sy saak te verloor (,vare”). Ook kan die teëparty in formalistiese reëls aanleiding vind tot chicanes.

Om aan hierdie gevare te ontkom is daar net één middel: om die stryd met woorde om te sit in 'n stryd met wapens, wat as sodanig by die ou-germane voorrang geniet. Hier het ons die tweegeveg volgens die primitiewe opvatting van die reg van die sterkste. Dit staan buitekant die proses, maar dit is wel deeglik wetlik geoorloof. Hierdie tweegeveg heet in oud-Duits "Verfahren ohne Recht", teenoor die proses wat „Verfahren mit Recht" genoem word, of in oud-Noors: „,medh lög".')

'n Man wat so'n tweegeveg verloor, word daardeur eerloos en dit staan gelyk met regteloos, d.w.s. hy het nie meer reg op die ere-regte van sy stand nie: weergeld en boete. By die Skandinawiërs word hy selfs "Niding” - 'n nikswaardige, daar word 'n "Neidstange" voor sy huis opgerig (Ysland) en hy verloor die reg om tot die eed of tot die getuieverklaring toegelaat te word. ${ }^{6}$ ) Vanweë hierdie regsgevolge van die bogenoemde tweegeveg word dit op die duur noodsaaklik om dit wetlik te reglementeer. Vanaf hierdie moment vervang dit nie meer die proses nie, maar word dit self 'n vorm van proses en wel - volgens germaanse opvatting - die hoogste vorm: ,ultima ratio legis". Nou word die tweegeveg ook gevolg deur die regterlike vonnis en eers dan kan ons werklik spreek van 'n gèregtelike tweegeveg, 'n duellum.

Uit die bostaande ontwikkeling blyk tewens dat die tweegeveg geen bewysmiddel was en dus geen godsoordeel kon wees nie; in oud-germaanse tye het alleen eed en getuienis bewyskrag gehad, later ook die egte godsoordeel.

Die oorgang van hierdie geregtelike tweegeveg tot die groep van die godsoordele is bevorder deurdat die tweekamp soms as orakel diens gedoen het.

In die algemeen het die uitslag van 'n stryd by die ou-germane somtyds as orakel gegeld. By uitsondering het die orakel in die ou-germaanse reg naas eed en getuienis as bewysmiddel diens gedoen; byvoorbeeld die orakel van die lot en van die baar-reg om die dader van 'n geheime misdaad uit te vind. Dit is begryplik dat die duellum, as orakel in 'n proses gebruik, gemaklik vir 'n godsoordeel gehou kan word.

5) vgl. die Njala-saga c. 56, waar Geirr vir Gunnarr sê: ,mantu tha skora mer a holm, sem thu ert vaur, ok thola eigi lög?": "wil jy my uitdaag tot 'n tweekamp, soos dit julle sede is, en die wet ontwyk?"

9) Vgl. die merkwaardige beskrywing van hierdie gebruike in $\mathrm{K}$. WeINHOLD, „Altnordisches Leben”, p. 298 vlg. 
Dit was egter onder invloed van die christelike kerk dat die geregtelike tweegeveg tenslotte by die godsoordele ingelyf is op die wyse wat vasgelê is in die „leges barbarorum".

Vanouds was die godsoordeel 'n bewysmiddel. Die Germane het dit egter slegs oorgeneem as 'n subsidiêre bewysmiddel: tot bevestiging van ' $n$ gewraakte eed of by onstentenis van eedhelpers. Die godsoordeel was ' $n$ kerkelike instelling, daar is altoos 'n liturgie aan verbind, wat nou dus ook oorgedra sal word op die geregtelike tweegeveg.

Dit is natuurlik onmoontlik om die direkte bewys uit die skriftelike. bronne te lewer, dat die christelike kerk aan die duellum die karakter van 'n godsoordeel opgedwing het want soos ons sal sien is die vermoedelike motiewe nie van so 'n geaardheid nie dat die kerk hulle op skrif sal stel. Of hierby I Samuel 17 vs. 47 ook 'n rol gespeel het, is ons nie bekend nie.

Die duellum, in sy oorspronklike gedaante deur en deur onchristelik, is al te seer ' $n$ nasionale kultuurgoed van die Germane, dan dat die kerk dit sou kan uitroei. Dit lê dus voor die hand, dat die middeleeuse christelike kerk, met sy verwonderlike aanpassings- en absorbsievermoë vir heidense instellings, ook die geregtelike tweegeveg, wat nie kon uitgeroei word nie, eers tot 'n godsoordeel omgevorm het om dit onder sy invloed te kry, vervolgens getrag het om dit deur ander, minder bloedige, godsoordele te vervang.

Slegs in 'Skandinawië vind ons 'n ander ontwikkeling, maar dit is juis 'n sterk bewys vir ons stelling: 'Die Christendom het eers baie laat in hierdie lande deurgedring. Toe dit vaste voet gaan kry het, was die duellum reeds op 'n verskriklike manier ontaard. In die 10e eeu kan 'n mens sê, dat dit 'n wettig gesanktioneerde reg van die sterkste geword het, en g'n mens wat reg gesoek het was meer veilig vir die bedreiging met 'n bloedige geveg. Hier kom die kerk dus te laat om die kerstening van 'n geregtelike tweegeveg deur te druk, en kon die nuwe christelike leer dus niks anders doen as om die misbruik met alle krag te bestry. So sien ons dat in Ysland kort na die invoering van die Christendom in die jaar 1004 die ,fimtardom" of ,vyfde gereg”, ingestel word, waardeur elke regsoekende die keus tussen 'n ,gesworene"'-hof of 'n duellum gekry het. Reeds in 1011 egter word die laaste keus nie langer toegelaat nie, terwyl in die volgende jaar koning Eirikr Hakonarson die duellum in Noorweë, wat omstreeks 1000 tot die Christendom oorgegaan het, vir goed verbied het. $\left.{ }^{7}\right)$

In Wes-Europa egter, waar die kerk bytyds ingegryp het, het die duellum soseer 'n christelike instelling gaan word, dat 'n tyd lang die kerk self sig daarvan bedien het as sy in hofsake gewikkel word. Die eienaardigste verskynsel op hierdie gebied is wel die geregtelike tweegevegte wat somtyds tussen lede van die kerk as verteenwoordigers van

7) vgl. vir die „fimtardom": Njala, cap. 98; vir die afskaffing in Ysland: Gunna laugs Ormstungu saga, cap. 11; vir die afskaffing in Noorweë: Gretla, cap. 21. 
geskilvoerende kerklike organisasies geveg is, terwyl die toppunt wel bereik word in tweegevegte tussen priesters! ${ }^{\natural}$ ) Hierby moet ons egter nie vergeet nie dat baie geestelikes uit die adellike stand afkomstig was en veelal maar min van hulle wêreldlike gewoontes afgelê het by hulle intree in kerk of klooster, en op hierdie gewoontes is baie sterk die stempel afgedruk van die „chevalerie”, die ridder-ideale, insluitende die tweegeveg.

Miskien het ons selfs te ver gegaan, toe ons die omvorming van die duellum tot 'n christelike godsoordeel geheel aan 'n bewuste strewe van die kerk toegeskryf het. Want wie kan sê in hoever die middeleeuse volke met hulle sterk ontwikkelde geloof aan wondere en aan die direkte inmenging van God in alle dinge van die aldagse lewe self in die tweegevegte godsoordele gaan sien het?

Hoe dit mag wees: ons kan in elk geval sê dat die christendom die geregtelike tweegeveg tot 'n godsoordeel gemaak het, waardeur dit tereg gekom het in die groep van onegte godsoordele, namelik dié waaraan altwee partye deelneem, soos die beslissing deur die lot en die kruisproef. Eers as 'n godsoordeel het die tweegeveg tewens bewyskrag gekry en, dit is in hierdie dubbele hoedanigheid van ,godsoordeel-bewysmiddel" dat ons die duellum in die ,leges barbaorum" aantref.

Op grond van ons ondersoek van die "leges barbarorum" is ons geneig om die ontwikkeling van die geregtelike tweegeveg tot 'n christelike godsoordeel te dateer in die eerste twee eeue na die Volksverhuising.

Ons vind egter ook dat die Kerk reeds in die 9e eeu die tweede stap gedoen het deur 'n begin te maak met die bestryding van die geregtelike tweegeveg qua godsoordeel, met die bedoeling om dit deur 'n meer humane regspleging te laat vervang.

Die beste kan ons hierdie ontwikkeling volg in die Franke-ryk.") Daar is die oudste dokumente wat ons het die Edikt van Lyon van Koning Gundobad in 501, wat 'n sterk styging van die getal tweegevegte in die Frankiese ryk tengevolge gehad het, al beperk dit die reg om 'n duellum toe te staan nog tot die koning se eie geregshof. Die wetgewing van die christelike Karolingiese koninge - vervat in die capitularia het die tweegevegte nog sterker laat toeneem, veral deurdat hulle die laer howe eweneens die reg gegee het om 'n duellum toe te staan. In die 9e eeu begin die Kerk en bind die stryd hierteen aan: die Konsilie van Valence spreek sig in 855 ondubbelsinnig teen die tweegeveg uit (canon 12). Dit het nie die minste uitwerking gehad nie, ewemin as 'n gelyksoortige besluit van die Konsilie van Limoges in 994 . Hoe kon dit ook anders, as die Pouse self die tweegeveg nog toelaat in kerklike hofsake, soos Johannes XIII nog in 907 gedoen het? 'n Nuwe ritus het

8) Byv. in 1026: sien „Hist. Gén. de Languedoc” II p. 159.

-) Uit die omvangryke literatuur noem ons slegs: A. Counn: „Verfall des offiziellen und Entstehung des privaten Zweikampfes in Frankreich". 
selfs opgekom om die inmenging van God in die uitslag as 't ware af te dwing: die aflê van allerhande eedsformules deur altwee partye. Hierdeur word nou in elke tweegeveg tenminste een meineed afgelê, terwyl die duellum party keer juis ingestel was om meineed deur getuies te voorkom. Die verbastering is dus duidelik!

'n Bydrae in die stryd teen die duellum-godsoordeel wat die Christendom tot groot eer strek is die twee boeke van die kerkvader Agobardus, aartsbiskop van Lyon van $814-840 .{ }^{10}$ ) Dit is uiters skerpsinnige geskrifte, maar die enigste resultaat wat hy bereik is, dat hy aan latere teenstanders van die geregtelike tweegeveg 'n skat van argumente daarteen aan die hand gedoen het.

Die enigste beperking van die tweekampe het sover van 'n geheel ander kant gekom: die feodalisme verbied tweegevegte tussen adel en volk, tussen ridder en nie-ridder, met hulle totaal verskillende bewapening. Hieruit ontstaan die idee van die gelykheid van partye, $\left.{ }^{11}\right)$ wat nou ook uitgebrei word oor: gelykheid van nasionaliteit, gelykheid van godsdiens, en gelyke verhouding teenoor die Koningsvrede en die Godsvrede. Dat hierdeur heelwat moontlikhede vir 'n duellum uitgesluit word, is duidelik.

Die meeste regters egter bly groot voorstanders van die tweegeveg, omdat dit hulle - in teenstelling met die enquête-regspraak - van elke verantwoordelikheid vir die uitspraak onthef het. ${ }^{12}$ )

In die begin van die $12 \mathrm{e}$ eeu kry die teenstanders van die duellum egter 'n belangrike kampioen vir hulle saak in Bernari van Clairvaux, "die geestelike orakel van die aandland". Sy bestryding van die duellum sal wel gelei het tot die vrystelling wat ons weet dat kort na 1100 aan alle geestelikes verleen is, al duur dit tot na 1200 voordat die kerk die duellum in a 11 e kerklike sake gaan beperk. Innocentius II is die eerste Pous wat sig teen die tweegeveg uitspreek en wat ook priesters wat sig daaraan skuldig maak in die jaar 1140 afgesit het. Pous Alexander III verbied die veg van elke geregtelike tweekamp deur geestelikes in 1171 en Gregorius IX verwerp die duellum ook vir die leek. Dit egter nog sonder sukses. Die dertiende eeu begin met 'n besluit van die Lateraankonsilie van 1215 wat elke hulp of medewerking van die kerk by die organiseer van tweegevegte verbied (canon 18). Wederom sonder sukses. Ook die algehele verbod van die geregtelike tweegeveg deur die konsilie van Saint Quentin in 1234 moet onder die ,pia vota" gereken word. Miskien was dit maar gelukkig, want die ander stroming in die kerk: om stadigaan die invloed van die kerk by die organiseer van die twee-

10) „Liber adversus legem Gundobadi etc.”, en „Liber de divinis sententiis etc.”, altwee in Migne se "Patr. Lat." CIV.

11) Die begrip "gelykheid van partye" is eintlik reeds oud-germaans en dit bly voortbestaan in die moderne duel. Vgl. die "Statisfaktionsfähigkeit" by die heden. daagse Duitsers, wat nog net so primitief is as 2000 jaar gelede.

12) vgl. J. Declareuil in "Nouv. Revue Hist. de Droit français etc." 1909, p. 92 vlg. 
gevegte uit te brei, het baie meer sukses. Op grond van die godsoordeelkarakter van die duellum kon die kerk altoos meer uitbreiding gee aan die godsdienstige formaliteite by die duellum, wat deur 'n geestelike moes verrig word. In hierdie medewerking van die kerk by elke duellum lê juis die kiem van die verval: As die kerk eenmaal magtig genoeg is om die tweegeveg in die kerkreg te verbied, is die tyd nie meer ver nie, dat die medewerking aan die tweegeveg in die wêreldlike reg kan geweier word, waardeur die tweegeveg as godsoordeel onmoontlik gemaak word.

In die $12 \mathrm{e}$ eeu het die kerk in sy stryd teen adel en regterlike mag, wat die tweegevegte wil handhaaf, magtige bondgenote gekry in die kòninge en in die burgers van die nuut opgekome stede. Die nuwe stede was handelsentrums en hul belange word bedreig deur ' $n$ tweekampreg wat 'n vreemde koopman, as hy daar besigheid wil doen, moet laat vrees dat hy in 'n hofsaak, dus in 'n geregtelike tweegeveg, verwikkel kan word. Veral die Vlaamse en Noord-Franse handelsgildes het die kerk in hierdie opsig gesteun en reeds in 1116 word die stad Yperen van die duellum vrygestel. Die Nederlandse stede in die Noorde het eers in die 14e eeu gevolg: Amsterdam in 1340.

Behalwe dat die kerk sterk by die koninge op inperking van die duellum aangedring het, het die vorste ook 'n direkte belang daarby: Van 'n hofsaak wat met getuiebewys beslis word deur 'n laere hof is daar beroep op die koning se geregshof; word 'n saak deur 'n tweekamp beslis dan is daar nooit beroep nie. Veral dié Franse koninge wat na versterking van hulle sentrale mag gestreef het, het dus in hierdie opsig die kerk gesteun, beginnende met koning Lodewyk VII. Hulle gee aan Franse stede privileges wat die enquête in die proses-reg verpligtend stel, soos in Avignon in 1252, waarin die duellum selfs nie meer genoem word nie.

Die mylpaal vorm egter die besluite van die vrome (maar tegelyk absolutistiese!) Lodewyk IX, die Heilige. Onder invloed van die clerus gee hy die voorbeeld deur sy ordonnansies van 1254 en van 1258, wat in die koning se eie domeine respektiewelik vir siviele-en vir kriminele sake die duellum vervang deur die enquête. Ook die groot juriste van die tweede helfte van die 13e eeu, soos Fontaines en Beaumanoir het die kerk en die koning in die stryd teen die tweekamp gesteun. ${ }^{13}$ )

Koning Philips IV gaan nog 'n stap verder in sy "Ordonnance” van 1304 wat die tweekamp beperk tot sake van moord, verraad of geweld, wat nie deur getuies of op ander maniere bewys kan word nie. Eers in 1409 is egter bepaal dat slegs die Kroon of die Parlement van Parys ' $n$ geregtelike tweegeveg kon toestaan. Dit was die genadeslag,

13) Vgl. „Les établissements de Saint Louis" in die edisie van P. V1OLlet, wat in sy inleiding veel wetenswaardigs oor die duellum meedeel. Ons ondersoek is egter bemoeilik deurdat die $13 \mathrm{e}$ eeuse juriste in hulle werke hul legistiese verlangens omtrent die enquète as ge $1 \mathrm{~d}$ e $\mathrm{nde}$ reg voorstel: Vgl. "Les coutumes du Beauvoisis" van Ph. de Benumanoir, ed. Beugnot en die „Conseils” van P. de Fontaines, ed. Marnier. 
aangesien die toestemming meesal geweier is. Die vertroue van die volk is veral geskok deur 'n duellum van 1385 tussen Jacques Legris en Jean Carronge, wat deur die koning bygewoon is en waarin Legris gedood is, terwyl later uit getuieverklarings geblyk het, dat hy volmaak onskuldig was.

Tog bly die duellum as bewysmiddel en as godsoordeel voortbestaan vir die gevalle van die ordonnansie van 1304. Die laaste geregtelike tweekamp in Frankryk was in 1547 in teenswoordigheid van Hendrik II, waarby die koning se gunsteling gedood is. Hy het toe 'n eed afgelê om dit nooit weer toe te staan nie. Geen wet het dit egter ooit opgehef!

As 'n merkwaardige besonderheid moet ons nog daarvan melding maak dat in geen staat ter wêreld die geregtelike tweegeveg soseer in ere was en so in besonderhede gereel was as in die Koninkryk Jerusalem, die stigting van die christelike Kruisridders. Deur die ,reverentia majorum" en die absolute heerskappy van feodalisme in die christelike Ooste, weerspieël die wetboeke van Jerusalem die toestand in Frankryk voordat die koninge die duellum gaan bestry het, 'n periode waaroor ons uit Frankryk self amper geen bronne het nie. ${ }^{14}$ )

Vir Engeland is daar geen enkele bron om te bewys dat die duellum daar voor 1066 bestaan het. Die Beowulf noem dit nie en mens sou al die ou regsboeke moet deurlees om sekerheid te kry. Ons neem dus aan dat Willem die Veroweraar dit ingevoer het, oorspronklik alleen as altwee partye Normandiërs was. Hoewel dit uitbrei met die vermenging van Angelsakse en Normandiërs het dit nooit werklik populêr geword nie. Dit is vernaamlik gebruik in hofsake weens felonie, verraad en „nova desseisina" (onregmatige inbesitneming van land). Onder invloed van die kerk en van die ,justitiarius" Ranulph de Glanville begin die bestryding reeds onder koning Hendrik II wat omstreeks 1185 in hofsake oor landbesit 'n keus tussen duellum en ,veredictum" deur gesworenes toegelaat het, maar . . . dit is hy wat die gesworenes aanwys, dus wederom vind ons naas die christelike die absolutistiese motief. ${ }^{15}$ ) Honderd jaar later het Eduard I in hierdie sake die duellum verbied. Dit het nou vry spoedig algeheel in onbruik geraak en dit was onnodig vir die kerk om die fel stryd te voer wat op die kontinent moes gevoer word. Tog is dit nooit offisieel afgeskaf nie. Nog in 1571 hoor ons daarvan, terwyl ons die geval Thornton in 1817 reeds tevore genoem het. Merkwaardig, maar suiwer formeel, is die hof-amp van ,die koning se kampvegter", wat tot vandag toe bestaan „om die koning - hoof van die Engelse Kerk - in geregtelike tweegevegte te verteenwoordig as die Kroon in 'n hofsaak uitgedaag word"! 1841.

15) Die wetboeke is saamgevat in die „Assises de Jérusalem”, ed. Beugnot, Parys

16) vgl. R. De Glanvil le, „Tractatus de leg. et consuet. regni Angliae”, passim. 
'n Paar afsonderlike opmerkings wil ons nog aan die ontwikkeling van die duellum in die Nederlande wy. ${ }^{16}$ ) Hoewel ons van die oudste middeleeue hier niks weet nie, is daar geen rede om aan te neem dat toestande van die orige dele van die Franke-ryk sou verskil het. Die kerk se bemoeiings met die duellum en later die kerk se bestryding daarvan sal ook hier hul invloed laat geld het. Maar merkwaardig is, dat 'n outochtone beweging teen die tweekamp hier eers honderd jaar na Frankryk ontstaan. Die oudste stadbrief wat verbied om burgers uit te daag tot 'n ,kamp" - soos die geregtelike tweegeveg in ou Nederlandse bronne meesal genoem word - is die van Zutphen in 1190.17) Middelburg volg in $1217 . .^{18}$ )

Teen die midde van die $13 \mathrm{e}$ eeu kom dan die stadsprivileges wat die kamp òf totaal afskaf ò wel nie meer verplig stel nie; Leiden in 1266: „.. . nec ad examen duelli poterit aliquatenus provocari". ${ }^{19}$ ) Tog bevat die keur wat graaf Floris die Voogd in 1258 aan die provinsie Zeeland gee nog baie uitvoerige tegniese voorskrifte, hoe om 'n duellum te hou.

In 1290 - amper gelyktydig met Frankryk - word in Zeeland deur graaf Floris $V$ 'n poging gedoen om die tweegeveg kompleet af te skaf. R. FruIN, wat die keure van 1259 en 1290 vergelyk het, ${ }^{20}$ ) trek ten onregte die konklusie dat in die tussegeleë 30 jaar die waarde wat aan die duellum geheg word, soseer verminder is, dat dit as 'n bewysmiddel uitgedien het. $\left.{ }^{21}\right)$ Die $14 \mathrm{e}$ eeu toon in Zeeland sowel as in Holland, weer 'n groot oplewing van die gebruik, sodat ons waarskynlik Floris se poging moet sien as 'n uiting van sy absolutistiese strewe, wat algemeen bekend was. In die $14 \mathrm{e}$ eeu onderhou die grawe van Holland nog altyd ,krijthoven" in die verskillende stede, d.i. die offisiële ,ring", waar die tweekampe gehou word. Hulle het ook nog „,kempen": beroeps-kampvegters, wat teen ' $n$ vaste salaris beskikbaar is om in die plek van die graaf te veg!

In die $14 \mathrm{e}$ eeu word egter stadigaan die tweegeveg vervang deur die „waerhede" (= verelictum), die Hollandse vorm van die enquête: „Voort waer dat sake, dat onse baili (landdrost!), of iemant van onsen weghe, enighen mensche . . . te campe anesprake van dootslaghe of van vredebrake, so sal dieghene die men anespreect, die waerheyt hebben, also verre als hi se begeert." 22 )

Dit geld egter alleen vir die platteland: in die stede is dit nie die ,waerhede" nie, maar 'n verwante prosesvorm, die ,kenning", wat die duellum verdring. Dit was FruIN, wat aangetoon het, dat die kenning

18) Sien vir Holland o.a.: P. Voet, „De duellis"; K. van Alkemade „Kampregt der Hollanderen" en P. VAN DER Schrlling "Kampen en duelleren", en die genoemde studie van $R$. Fruin.

17) Vgl. SLoET, „Oorkondenboek van Gelre en Zutfen”, I 376.

18) Vgl. VAN DEN Bergh, ,Oorkondenboek van Holland etc." I no. 261.

19) VAN AlKemade, 1.c. p. 190-203.

20) Die tekste in: VAN DEN Bergh I. c. II no. 40 en II 747-748.

11) R. Fruin, l.c.p. 321.

22) R. FrUin, l.c.p. 337 . 
eintlik 'n geregtelike tweegeveg . . . op papier is: die een party deponeer sy wedde (engels ,wage") en eis daarmee 'n ondersoek wat tot 'n kenning lei. Dit is die "legem vadiare" of ",kamp bied" deur middel van 'n pand (die neergeworpe handskoen) in die duellum. Die ander party verbind sig tot die ,kenning" deur 'n teen-wedde, net soos by die duellum. Die persoon wat 'n kenning weier het sy saak verloor, net soos outyds by die weiering om 'n kamp-duellum te aanvaard. En die "skepene" (heemrade!) gee die kenning aan een van die partye gewonne, net soos die kampregters die duellum gewonne gee. Maar die wapens is vervang deur die ,dingtale" - die pleidooie en eise wat partye by die skepene indien: 'n duellum op papier!

Tog neem dit nog twee grafelike handveste: van 1303 vir SuidHolland en van 1346 in Noord-Holland, en 'n groot aantal stadskeure: o.a. Amsterdam en Rotterdam in 1340, Hoorn in 1356 - voordat die waerhede en die kenning die oorhand kry oor die duellum. In 1402 word daar in Noord-Holland weer 'n duellum met skerp ridderwapens geveg. ${ }^{23}$ ) Dele van Holland kry eers in 1476 kampvrydom (Workom) en dat die "groot keur" van Zeeland (cap. IV, art. 11) dit in 1495 verbied, is juis 'n bewys dat dit toe nog bestaan het. Trouens, die juris DAMHOUdere ken dit nog in sy groot handboek „Praxis rerum criminalium" wat in 1555 verskyn het. Alles bewyse dat die geregtelike tweegeveg eers baie laat, later as in ander Wes-Europese state, in die Nederlande verdwyn het. Wat is hiervan die verklaring?

Dit tref ons dat in die Nederlande die tweegeveg minder as elders die karakter van 'n godsoordeel aangeneem het. Ontstaan uit die „ultima ratio legis" het dit - soos FruIN betoog - die wet by uitnemendheid, die "lex apparens" gebly. Art. 40 van die keuı van 1258 praat nog van: "Intrabit cum pugile suo pro $l \mathrm{e} g$ e sua facienda". Is ons teorie omtrent die ontstaán van die godsoordeel-karakter van die tweegeveg korrek, dan moet ons dus die bogenoemde verskynsel toeskrywe aan 'n minder diepgaande invloed van die Kerk van Rome in die Nederlande as in die ander state van Europa.

Dit egter is 'n verskynsel wat in die kerkgeskiedenis van 'n algemene bekendheid is. Dit word deur party outeurs aangevoer as een van die verklarings vir die sukses van Protestantisme in die Nederlande. Onwillekeurig dink ons nou ook terug aan die ontstaan van die „,kenning”, die gesiviliseerde vorm van die tweekamp op papier. Ons sien daarin 'n tipies Nederlandse poging om die kwaad van die geregtelike tweegevegte te bestry met 'n nuwe, burgerlike instelling. En weer moet ons sê: dat nie die geestlikheid nie, maar die stadsburgerye die voortou geneem het in die stryd teen die duellum, is 'n gevolg van - maar tewens ' $n$ nuwe bewys vir: die feit dat die Roomse Kerk in die Nederlande minder invloed gehad het as elders. Wel is waar het die kerk sig reeds in 1217

23) Volgens FruiN in: „Vaderlandsche Chroniick” p. 569 en 758. 
teen die tweekamp verklaar, maar die abdis van die vroue-klooster van Rijnsburg het nog in 1383 'n sekere Willem Constantsz tot 'n duellum met haar kampvegter laat uitdaag. ${ }^{24}$ )

'n Laaste besonderheid: die tweegevegte was in die Nederlande, juridies beskou, net so onregverdig en onbevredigend as in ander state; maar, algemeen menselik beskou, was hulle baie "minder wreed en bloedig. Behalwe in die duellum tussen edelliede, wat ook hier steeds met skerp ridderwapens geveg is, was die gewone bewapening van partye: 'n swaar kopkierie en 'n skild. Dat dit opsigself nie 'n waarborg teen onmenslike wreedheid is nie, bewys die dramatiese beskrywing van ' $n$ duellum tussen twee burgers van die Noord-Franse stad Valenciennes, wat ons vind in die kroniek van Chastellain.25) Dit vind plaas in 1455 in teenwoordigheid van hertog Filips van Boergondië en die partye heet Mahuot en Jacotin Plouvier. Ondanks die uitsluitlike gebruik van knods en skild, en met alle bystand van die kerk, wat partye die Evangelie laat kus, die skilde met heilige figure laat beskilder, en die stryers vrome spreuke in die hand laat hou, laat Jacotin vir Mahuot sand byt, en spring hom op die rug, om sy arms te verdraai en hom die rug te breek. Mahuot byt Jacotin 'n vinger af, maar Jacotin druk met sy duim vir Mahuot die oë uit sy kop, sodat hy beswyk. Die sterwende Mahuot word dan op las van die kampregters as oorwonne party aan die galg gehang!

Vergelyk hiermee nou die kamp met dieselfde wapens in die Nederlande, soos voorgeskrywe in die keur van Zeeland van 1258: „So wanneer twee kempen sullen vechten: die verwonnen sal heeten, hy sal vallen op d'aerde of men sal ne (hom) werpen op d'aerde of jaghen over die 'ine uten crite (uit die strydperk), ende se sullen vechten met mindere wapenen (knopkierie en skild). Wie se kempe wort verwonnen, hy sal den kempe, die sege vecht, gheven vier mark (omtrent vier shillings)."26)

Dit is nie die kerk wat die oorsaak is van hierdie bepalings nie, wat meer gelykenis vertoon met die reëls yan 'n moderne vuisgeveg as met die van die moorddadige oud-germaanse duellum, en wat geld vir 'n stryd tussen vir die doel gehuurde kampvegters. Hierdie bepalings is eensdeels die gevolg van die tipies-burgerlike afkeer van die vulgêre stryd, wat die" Nederlanders later met huurtroepe oorlog laat voer het; anderdeels is dit ' $n$ gevolg van die eweneens tipies-Nederlandse humaniteit en sagmoedigheid, waarvan Erasmus aan die einde van die Middeleeue die groot prediker geword het.

M. BOKHORST

24) Vgl. P. C. MolhuYsen ,De Vuurproef en de Gerechtelijke Tweekamp in de. 14e eeuw", Nijhoff's Bijdragen, N.R.I.

25) Vgl. J. Huizinga „Herfsttij der Middeleeuwen” le dr. p. 154-157.

26) vgl. R. FruIn, l.c.p. 325 . 


\section{BronNE.}

Behalwe die reeds aangehaalde werke wil ons hier nog 'n paar van ons bronne noem:

Uit die baie ryk literatuur oor die geregtelike tweegeveg - ons ken meer as sestig werke wat net oor hierdie onderwerp handel - vermeld ons diegene wat in besonder die houding van die kerk behandel:

Mons. B . . . „Dissertation historique sur les duels etc." Mons. B . . . is die Hugenote-predikant JACRues BASNAGE wat toe (1720) in Den Haag gestaan het.

HopmanN: „Die Stellung der Katholischen Kirche zum Zweikampf etc." Ztschr. f. Kath. Theol. 1898.

P. Marchegay: „Le duel judiciaire entre des communautés religieuses. Bibl, de l' école des Chartes". t.I.

A. Saplayrolles: "Recherches sur le duel judic. et la doctrine ecclésiastique".

De Smedt: „Le duel judic. et l'Eglise”, Etudes religieuses t. LXIV.

Uit die algemene werke wat hoofstukke oor die geregtelike tweegeveg bevat noem ons net nog 'n paar:

Ducange: "Glossarium etc." i.v. „duellum" en die ,dissertatio" no. VII.

Hoops: „Reallexicon d. germ. Altert. k." i.v. „Zweikampf”.

EsmeIN: „Hist. de la procédure criminelle en France", passim.

Von Amira: in Paul's Grundriss der germ. Philologie" III 203-220.

Schopenhauer: „Sämmtliche Werke" V 396 vlg.

J. van Lennep: „Het Godsoordeel”.

M. B. 